ISSN $1978-3000$

\title{
Pengaruh Leaching terhadap Komposisi Nutrisi Bakso Itik Talang Benih
}

\author{
Effects of Leaching on Nutrient Composition of Talang Benih Duck Meat Ball \\ Olfa Mega
}

Jurusan Peternakan Fakultas Pertanian Universitas Bengkulu

Jalan Raya Kandang Limun Bengkulu Telp. (0736) 21170 Pst 219.

\begin{abstract}
The aim of the present study was to evaluate the composition of nutriens of Talang Benih duck meat ball on different leaching frequency. The treatments were allotted to a completely randomized design with four leaching frequency $(0,1,2$ and 3 times) and three replications. Data were analyzed as a completely randomized experiment using the GLM procedure of SAS. The results of this research showed that leaching non significant effects $(\mathrm{P}>0,05)$ on moisture and ash content except protein and fat content decreased significantly, while carbohydrate had increased 21,79\% (P2) and 21,87\% (P3). Protein had decreased 2\% (P1), 9\% (P2) and 14\% (P3) and other hand fat had decreased 1\% (P1), 29\% (P2) and 27\% (P3) compared P0 respectely.
\end{abstract}

Key words: Talang Benih duck, leaching, meatball, nutrient composition

\begin{abstract}
ABSTRAK
Penelitian ini bertujuan untuk mempelajari komposisi nutrisi bakso itik talang benih yang dibuat dari bahan baku nikumi. Percobaan ini menggunakan Rancangan Acak lengkap, yang terdiri dari empat perlakuan yaitu P0 (tanpa pencucian), P1 (1 kali pencucian), P2 (2 kali pencucian) dan P3 (3 kali pencucian), masing-masing perlakuan terdiri dari 3 ulangan. Data dianalisis ragam dengan menggunakan prosedur General Linier Models (GLM) dari Statistical Analysis System (SAS) Program. Perbedaan antar perlakuan dilakukan uji lanjut dengan Duncan Muliple Range Test (Steel dan Torrie, 1995). Hasil penelitian menunjukkan leaching (pencucian) tidak nyata $(P>0,05)$ berpengaruhi terhadap kadar air dan kadar abu bakso tetapi nyata $(P<0,05)$ menurunkan kadar protein dan kadar lemak, sedangkan karbohidrat meningkat pada leaching 2 kali (21,79\%) dan 3 kali (21,87\%). Penurunan kadar protein berturut-turut pada P1, P2 dan P3 adalah 2\%; 9\% dan 14\%, sedangkan untuk kadar lemak turun sebanyak $1 \%$; $29 \%$ dan $27 \%$ dibanding P0.
\end{abstract}

Kata-kata kunci : komposisi nutrisi,bakso, itik talang benih, leaching

\section{PENDAHULUAN}

Bakso merupakan hasil produk olahan hewani yang sangat popular disemua lapisan masyarakat. Kesukaan konsumen terhadap bakso sangat subjektif berdasarkan rasa, bau dan teksturnya. Disamping itu kualitas bakso sangat beragam dan dapat ditinjau dari keempukan, rasa dan status gizi terutama proteinnya. Jenis daging yang biasa digunakan dalam pembuatan bakso adalah daging sapi, daging ayam dan ikan. Jenis daging dari ternak lain yang dapat digunakan adalah daging itik. Daging itik tidak umum digunakan sebagai produk daging olahan karena bau dan rasanya yang anyir dibanding bakso ayam dan bakso sapi (Mega et al, 2008), padahal daging itik merupakan salah satu sumber protein hewani yang potensial untuk dikembangkan. Berdasarkan hal 
tersebut perlu adanya cara pengolahan yang dapat mengurangi atau menghilangkan bau dan rasa yang anyir tersebut. Salah satu alternatif yang dapat dilakukan adalah dengan membuat nikumi itik sebelum dijadikan produk bakso.

Nikumi (surimi-like) adalah daging yang digiling kemudian dibersihkan dan dicuci dengan air dingin berulang-ulang sehingga sebagian besar darah, pigmen, bau, lemak dan protein larut air hilang. Surimi merupakan bahan antara untuk diolah menjadi produk-produk lanjutan yang membutuhkan sifat elastisitas daging seperti bakso, sosis, nugget, dan lain-lain serta dapat juga digunakan untuk forifikasi berbagai aneka produk olahan. Dalam pembuatan surimi perlu ditambahkan antidenaturan untuk mencegah denaturasi protein selama pembekuan atau kerusakan struktur protein selama penyimpanan. Antidenaturan yang banyak digunakan adalah sukrosa dan sorbitol. Penambahan sukrosa 8 persen sudah dapat mencegah denaturasi protein, tetapi menyebabkan rasa yang terlalu manis dan warna menjadi coklat sedangkan sorbitol adalah bahan pemanis alam yang tingkat kemanisannya seperlima dari sukrosa, penambahan sorbitol tidak menyebabkan warna coklat pada produk tetapi teksturnya menjadi lebih keras (Suzuki, 1981). Untuk itu penggunaan sukrosa hanya 4 persen sisanya diganti dengan sorbitol. Suryaningsih (2006) menyatakan komposisi $2 \%$ sukrosa dan $2 \%$ sorbitol memberikan karakteristik fisikokimia yang baik pada nikumi kuda, sapi dan domba. Penambahan natrium tripolyposfat maksimum 0,5 persen yang berfungsi untuk memperbaiki daya mengikat air dan memberikan sifat pasta yang lebih lembut pada produk olahan (Price dan Scweigert, 1987).

Penelitian ini bertujuan untuk

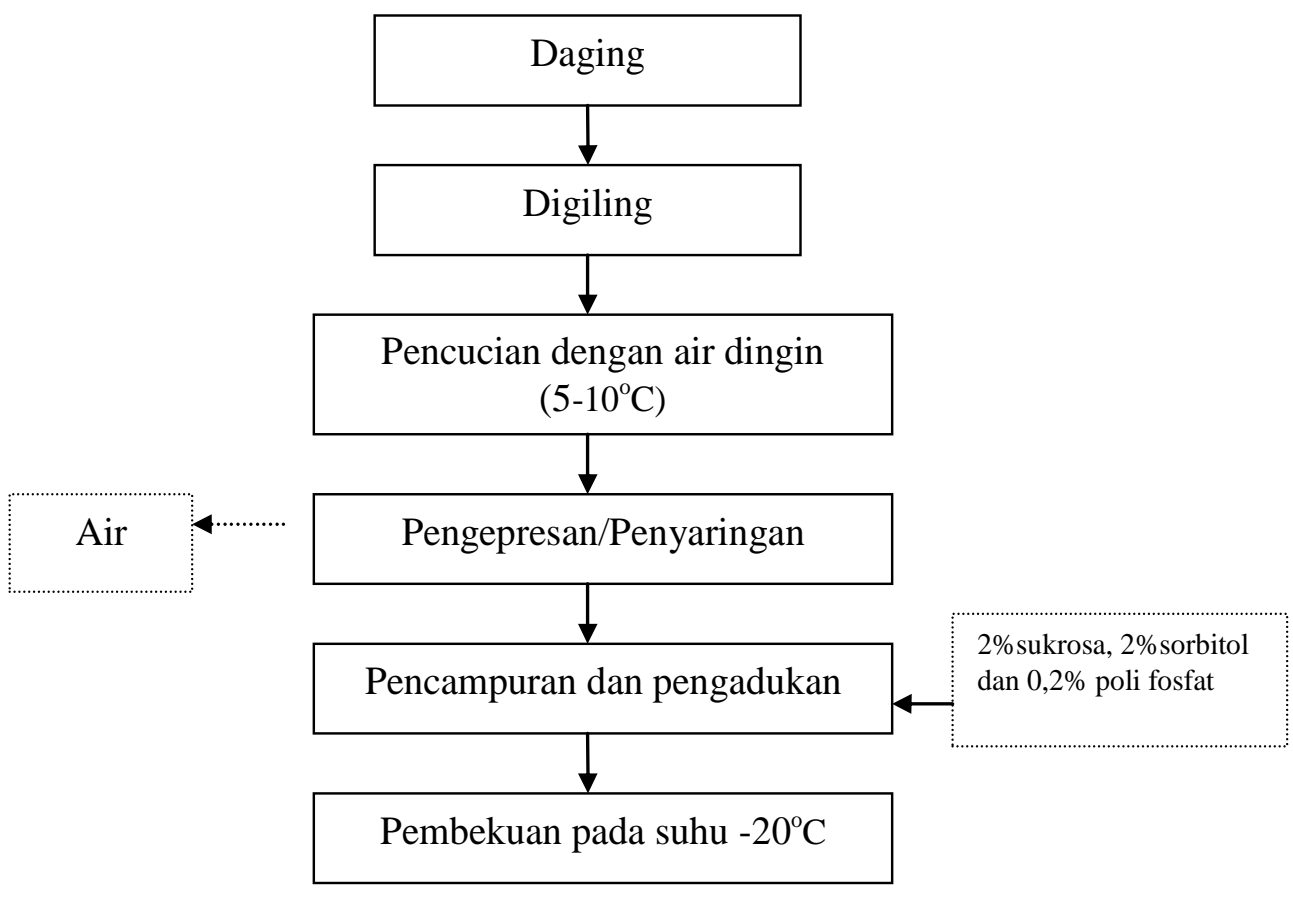

Gambar 1. Bagan proses pembuatan surimi (Suzuki, 1981) 
mempelajari dan mengevaluasi komposisi nutrisi bakso itik talang benih berbahan baku nikumi dengan perlakuan leaching yang berbeda.

\section{MATERI DAN METODE}

Percobaan ini menggunakan Rancangan Acak lengkap, yang terdiri dari empat perlakuan yaitu P0 (tanpa pencucian), P1(1 kali pencucian), P2 (2 kali pencucian) dan (P3 (3 kali pencucian), masing-masing perlakuan terdiri dari 3 ulangan.

Itik yang digunakan adalah itik lokal Bengkulu yang dikenal dengan nama itik Talang Benih karena itik ini banyak terdapat di Desa Talang Benih Kabupaten Curup Bengkulu.

Penelitian ini terdiri dari tahap pembuatan nikumi itik dengan perlakuan pencucian (leaching) 0, 1, 2 dan 3 kali dan tahap pembuatan bakso menggunakan bahan baku nikumi. Tahap pembuatan nikumi itik talang benih terdiri dari pemisahan tulang dan daging itik, penggilingan daging dengan meat mincer, pencucian daging dengan air dingin (suhu $5-10^{\circ} \mathrm{C}$ ), pengepresan menggunakan kain kasa dengan diameter lubang $\pm 0,5 \mathrm{~mm}$ atau \pm 28 mesh (Syarif,1989). Komposisi antidenaturan untuk semua perlakuan adalah sukrosa $2 \%$, sorbitol $2 \%$ dan poliposfat $0,2 \%$. Bahan tambahan yang digunakan adalah air es, tepung sagu, bumbu (bawang putih, merica) dan garam.

Peubah yang diamati adalah kadar air, kadar abu, kadar protein, kadar lemak dan kadar karbohidrat bakso (AOAC, 1995).

Data yang diperoleh dianalisis ragam dengan menggunakan prosedur General Linier Models (GLM) dari Statistical Analysis System (SAS) Program. Perbedaan antar perlakuan dilakukan uji lanjut dengan Duncan Muliple Range Test (Steel dan Torrie, 1995).

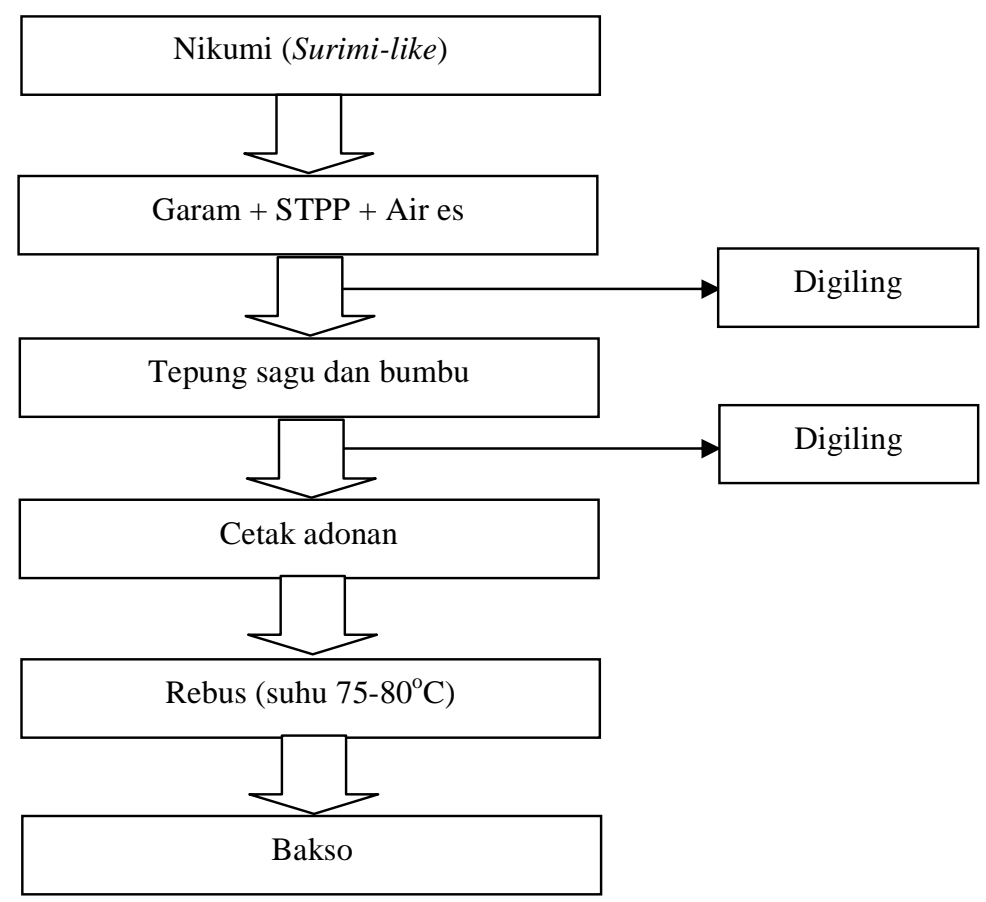

Gambar 2. Bagan proses pembuatan bakso (Sugiyono, 1992 


\section{HASIL DAN PEMBAHASAN}

\section{Kadar Air}

Air merupakan komponen utama penyusun daging yang dapat mempengaruhi penampakan, tekstur, cita rasa makanan itu sendiri. Semua bahan makanan mengandung air dalam jumlah yang berbeda-beda baik itu bahan makanan hewani maupun nabati. Air antara lain berperan sebagai pembawa zat-zat makanan dan sisa metabolisme.

Hasil analisis ragam menunjukkan bahwa leaching tidak berpengaruh nyata $(\mathrm{P}>0,05)$ terhadap kadar air bakso. Kondisi ini diduga jumlah air yang keluar pada saat pengepresan pada proses pembuatan nikumi relatif sama karena tekanan yang digunakan pada pengepresan juga sama. Menurut Srigandono (1997) daging itik mempunyai kandungan air sebesar 68,8\%, daging itik talang benih mempunyai kandungan air 74,92\% (Mega dan Jarmuji, 2007). Leaching yang berulang-ulang cenderung meningkatkan kadar air daging karena sifat hidrofilik daging. Penambahan garam $0,3 \%$ pada air pencucian terakhir akan mengurangi sifat tersebut, sehinggga kadar air bakso pada semua perlakuan tidak berbeda nyata.

Mega dan Jarmuji (2007) menyatakan bahwa leaching pada daging itik talang benih memisahkan protein 2 $4 \%$, kadar abu 3,60 - 5, 15\%. Namun demikian kehilangan protein dan abu tidak berpengaruh secara nyata terhadap produksi hal ini diduga karena jumlah daging dan bahan-bahan lain yang digunakan untuk pembuatan bakso pada tiap perlakuan relatif sama.

\section{Kadar Abu}

Kadar abu atau bahan anorganik daging terdiri dari mineral-mineral. Daging merupakan sumber mineral yang baik kecuali kalsium, karena sebagian besar kalsium terdapat pada gigi dan tulang.

Hasil analisis ragam menunjukkan pencucian daging itik tidak berpengaruh nyata terhadap kadar abu bakso nikumi itik $(\mathrm{P}>0,05)$. Rataan kadar abu bakso berturut-turut dari P0,P1,P2 dan P3 adalah $1,94 \% ; 1,87 \% ; 1,84 \%$ dan 2,06\%. Menurut Srigandono (1997) rata-rata kandungan abu daging itik adalah 1,2\%, sedangkan bakso daging sapi kadar abunya 1,75\% (Wibowo, 1995). Kadar abu daging itik talang benih adalah 1,07\% (Mega dan Jarmuji, 2007). Leaching cenderung menurunkan kadar abu bakso, tetapi pada perlakuan P3 kadar abu cenderung meningkat. Hal ini diduga karena adanya kontribusi dari garam $(0,3 \%)$ yang ditambahkan pada air pencucian terakhir, garam-garam tersebut kemungkinan masuk kedalam daging, sedangkan P0, P1 dan P2 tidak ditambahkan garam pada air pencuciannya. Garam merupakan bahan anorganik (abu), sehinggga kadar abu pada perlakuan P3 lebih tinggi.

\section{Kadar Protein}

Protein merupakan zat makanan yang sangat penting bagi tubuh, karena selain berfungsi sebagai bahan bakar

Tabel 1. Rataan kadar air, abu, protein, lemak dan karbohidrat bakso nikumi itik

\begin{tabular}{lcccc}
\hline \multirow{2}{*}{ Peubah } & \multicolumn{4}{c}{ Perlakuan } \\
\cline { 2 - 5 } & P0 & P1 & P2 \\
\hline Kadar Air & 70,04 & 70,54 & 70,40 & 70,89 \\
Kadar Abu & 1,94 & 1,87 & 1,84 & 2,06 \\
Kadar Protein & $13,85^{\mathrm{a}}$ & $13,55^{\mathrm{ab}}$ & $12,52^{\mathrm{bc}}$ & $11,82^{\mathrm{c}}$ \\
Kadar Lemak & $4,02^{\mathrm{a}}$ & $3,94^{\mathrm{a}}$ & $2,85^{\mathrm{b}}$ & $2,93^{\mathrm{b}}$ \\
Kadar Karbohidrat $^{*}$ & $10,15^{\mathrm{b}}$ & $10,10^{\mathrm{b}}$ & $12,38^{\mathrm{a}}$ & $12,37^{\mathrm{a}}$ \\
\hline
\end{tabular}

Keterangan: Angka diikuti superskrip yang berbeda pada baris yang sama menunjukkan berbeda sangat nyata $\left.(\mathrm{P}<0,01) ;{ }^{*}\right)$ by different 
dalam tubuh juga berfungsi sebagai zat pembangun dan pengatur dalam tubuh (Winarno, 1992).

Hasil analisis ragam menunjukkan bahwa pencucian sangat nyata $(\mathrm{P}<0,01)$ mempengaruhi kadar protein bakso. Hasil uji lanjut DMRT menunjukkan bahwa P0 $(13,85 \%)$ nyata lebih tinggi dari P2 $(12,52 \%)$ dan P3 $(11,83 \%)$ tetapi tidak berbeda nyata dengan P1 (13,55\%). P1 dan P2 tidak berbeda nyata tetapi nyata lebih tinggi dari P3, sedangkan antara P2 dan P3 tidak nyata berbeda. Kandungan protein $\mathrm{P} 0$ lebih tinggi dari P1,P2 dan P3, hal ini disebabkan karena pada P0 tidak dilakukan pencucian sehingga kandungan proteinnya masih tinggi. Nakai dan Modler (2000) menyatakan protein otot secara umum terbagi dalam tiga kelompok yaitu sarkoplasmik larut dalam air, miofibrillar larut dalam ion kuat dan stromal tidak larut dalam larutan garam tetapi larut dalam perlakuan asam dan alkali. Semakin banyak jumlah pencucian kandungan protein semakin menurun. Besarnya penurunan protein ini dibanding tanpa pencucian ( $\mathrm{P} 0$ ) berturut-turut untuk P1, P2 dan P3 adalah 0,89\%; 3,98\% dan $6,08 \%$.

\section{Kadar Lemak}

Lemak merupakan komponen utama penyusun daging. Diantara komponen lainnya, kandungan lemak tubuh seekor ternak sangat bervariasi tergantung pada umur, spesies, aktivitas dan nutrisi.

Hasil analisis ragam menunjukkan bahwa pencucian memberikan pengaruh yang sangat nyata $(\mathrm{P}<0,01)$ terhadap kadar lemak bakso. Hasil uji lanjut DMRT menunjukkan bahwa rata-rata kadar lemak bakso itik P0 (4,02\%) tidak berbeda nyata dengan $\mathrm{P} 1(3,94 \%)$ tetapi sangat nyata lebih tinggi dari P2 (2,85\%) dan P3 $(2,93 \%)$, sedangkan antara P2 dan P3 tidak berbeda nyata. Kandungan lemak tertingggi terdapat pada P0 yaitu 4,02\%, jumlah leaching atau pencucian cenderung menurunkan kadar lemak bakso, besarnya penurunan kadar lemak setiap perlakuan dibanding tanpa pencucian (P0) berturut-turut untuk P1, P2 dan P3 adalah 0,08\%; 1,17\% dan 1,09\%. Hal ini ini sesuai dengan pernyataan Lanier and Lee (1982), bahwa selama pencucian daging dipisahkan dari darah, pigmen, lemak, lendir dan protein yang larut dalam air.

\section{Kadar Karbohidrat}

Karbohidrat merupakan sumber kalori utama, kandungan karbohidrat dalam daging kurang dari 1\% dari bobot daging segar, sebagian besar karbohidrat berada dalam bentuk glikogen dan asam laktat.

Pencucian berpengaruh sangat nyata $(\mathrm{P}<0,01)$ terhadap kandungan karbohidrat bakso. Uji lanjut DMRT menunjukkan perlakuan P0 (10,15\%) dan P1 $(10,10 \%)$ sangat nyata lebih rendah dari P2 (12,38\%) dan P3 (12,37\%). Kadar karbohidrat dihitung berdasarkan selisih hasil bahan makanan terhadap kadar protein, lemak, abu dan air (Winarno, 1992). Dengan menurunnya kandungan protein dan lemak pada P2 $(2,85 \%)$ dan P3(2,93\%) maka kandungan karbohidrat P2 dan P3 lebih tinggi. Karbohidrat yang terdapat dalam daging (dalam bentuk

Tabel 2. Persentase perubahan nilai gizi bakso nikumi itik dibanding P0.

\begin{tabular}{ccccc}
\hline Perlakuan & & & Peubah (\%) & \\
& Abu & Protein & Lemak & Karbohidrat \\
\hline P1 & $-3,60$ & $-2,00$ & $-1,00$ & $-0,40$ \\
P2 & $-5,15^{\mathrm{b}}$ & $-9,00$ & $-29,00$ & $+21,97$ \\
P3 & $+2,00^{\mathrm{c}}$ & $-14,00$ & $-27,00$ & $+21,87$ \\
\hline
\end{tabular}

Keterangan : - = menurun, $+=$ meningkat 
glukosa dan glikogen) selain disimpan dalam hati (liver), glikogen juga disimpan dalam otot (Aberle et al, 2001).

\section{Perubahan nilai gizi}

Kandungan nilai gizi bakso itik sangat dipengaruhi oleh perlakuan leaching. Semakin banyak jumlah leaching kadar protein dan lemak cenderung menurun. Kandungan abu meningkat pada perlakuan P3 akibat penambahan garam pada air pencucian terakhir, kandungan karbohidrat juga meningkat pada P2 dan P3 dikarenakan kandungan gizi yang lain terus menurun.

\section{SIMPULAN}

Leaching (pencucian) pada daging itik Talang Benih tidak nyata mempengaruhi kadar air dan kadar abu bakso, tetapi menurunkan kadar protein dan kadar lemak, sedangkan karbohidrat meningkat pada pencucian 2 kali dan 3 kali sebanyak 21,97\% dan 21,87\%. Penurunan kadar protein pada pencucian 1, 2 dan 3 kali berturut-turut adalah $2 \%$, $9 \%$ dan $14 \%$, sedangkan lemak 1\%, 29\% dan $27 \%$.

\section{DAFTAR PUSTAKA}

Aberle, E.D., J.C. Forrest, , D.E. Gerrard and E.W. Mills. 2001. Principles of Meat Science. Fourth Ed. Amerika. Kendal/Hunt Publishing Company.

[AOAC] Official Methods of Analysis of the Association of Official Analytical Chemist. 1995. Washington D.C., USA.

Lanier, T.C and C. M. Lee. 1995. Surimi Technology. Marcel Dekker, New York.

Mega, O dan Jarmuji. 2007. Peningkatan mutu daging olahan itik lokal melalui penerapan teknologi surimi. Laporan Penelitian Fakultas pertanian Universitas Bengkulu, Bengkulu.
Mega, O.,.D. Kaharuddin, Y. Fenita dan Kususiyah. 2008. Karakteristik kimia dan organoleptik bakso daging itik manila. Jurnal Sain Peternakan Indonesia Volume 3 (1):17-24

Nakai, S. dan H.W. Modler. 2000. Food Proteins Processing Aplications. Wiley-VCH.,New York-ChichesterWeinheim-Brisbane-SingaporeToronto.

Price, J.F. dan B.S. Schweigert.1987. The Science of Meat and Meat product. 3ed Food \& Nutrition Press. In. Wesport. Connecticut USA.

Srigandono, B. 1997. Produksi Unggas Air. Gadjah Mada University Press, Yogyakarta.

Syarif, A.M. 1989. Teknik Pengolahan Hasil Pertanian. Terjemahan : Agricultural Process Engineering, Henderson, S.M and R.L Perry . 3M, Bogor.

Sugiyono. 1992. Penuntun Praktikum Teknologi pengolahan Pangan Hewani. Jurusan Teknologi Pangan dan Gizi. Fakultas Teknologi Pertanian. Institut Pertanian Bogor, Bogor.

Suryaningsih, L. 2006. Pengaruh jenis daging, penambahan antidenaturan dan natrium tripolifosfat pada nikumi terhadap karakteristik produk daging olahan. Disertasi. Sekolah Pasca Sarjana Institut Pertanian Bogor, Bogor.

Soeparno. 1998. Ilmu dan Teknologi Daging. Gadjah Mada Univ Press, Yogyakarta.

Steel, R.G.D. dan J.H. Torrie. 1995. Prinsip dan Prosedur Statistik. Suatu Pendekatan Biometrik. Edisi Kedua. Gramedia, Jakarta

Suzuki, T. 1981. Fish and Krill protein. Applied Sci Publisher, England.

Wibowo, S. 1995. Pembuatan Bakso Ikan dan bakso Daging. Penebar Swadaya, Jakarta.

Winarno, F.G. 1992. Kimia Pangan dan Gizi. Gramedia Pustaka Utama, Jakarta. 